\title{
Serological testing in a microbiology laboratory of specimens from patients with suspected infectious disease
}

\author{
D J Waghorn
}

\begin{abstract}
Aims-To determine how the microbiology laboratories of one region process serological requests from patients with suspected infectious illness, referred to as "clinical syndrome" type patients in this study; to consider areas where improvement in the associated serology service could be made.

Methods-A prospective two month collection of data on all serological requests from patients with suspected infectious illness was undertaken. A questionnaire on laboratory policies/procedures was also completed by the 10 departments taking part.

Results-Serology specimens from "clinical syndrome" patients accounted for $1-2 \%$ of total microbiology samples. There was significant variation in some of the policies/procedures carried out by the 10 laboratories when handling serological requests. Differences were seen in the use of laboratory protocols for test processing, range of tests performed, demand for second (convalescent) serum samples, storage of serum samples, and reporting of results.
\end{abstract}

Conclusions-The laboratory management of "clinical syndrome" type requests is complex. Individual pathology departments vary in the way they handle serology specimens but this study highlighted areas which may contribute to improving the appropriateness of testing and the more efficient use of serology resources. These include improving (1) clinician education, (2) pathology request forms to encourage better clinical information, (3) appropriate laboratory protocols to aid decision making on test selection, (4) percentage of convalescent serum samples received together with longer serum sample storage, and (5) turnround times of serology reports. (f Clin Pathol 1995;48:358-363)

Department of

Wycombe General Hospital. Queen Alexandra Road, High Wycombe HP11 2TT D J Waghorn

Correspondence to: Dr D J Waghorn. 19 July 1994
Over the past decade, there has been an increasing awareness and analysis of the appropriateness of laboratory tests. This has been stimulated by concern over both increasing costs of testing and a desire to improve the overall use of pathology services. ${ }^{1}$ To date, such studies have mainly been carried out by haematology ${ }^{2}$ or biochemistry ${ }^{3}$ departments where requests and tests are more easily defined and where increasing automation of laboratory methods permits easier systematic analysis of the tests performed. In microbiology laboratories a review of requests received and subsequent tests performed is more complex. Compared with haematology and biochemistry departments, there is often a greater need to interpret the clinical information given before deciding on which laboratory tests to perform. Results of primary testing may also stimulate the need for secondary tests. In no area is this more important than with blood samples received for serological examination.

All clinical microbiology laboratories across the United Kingdom will receive serum samples from patients who have presented to clinicians with a "clinical syndrome" suggestive of a possible underlying infectious disease, where the diagnosis requires serological investigations. The types of disease falling into this description can be relatively well-defined-for example, atypical pneumonia, or can be broad and vague-for example, post-viral illness. However, these types of clinical problem often need serological testing against a range of microorganisms including virological (Epstein-Barr, influenzae, coxsackie), bacteriological ( $\mathrm{Le}$ gionella, Mycoplasma) and parasitological (Toxoplasma) pathogens. When samples are received from such patients it may be difficult to decide on the most appropriate tests to perform. The information given on the request form is critical to the decision making process and the quality of that information is often poor. Even the basic completion of a patient's name, date of birth and sex can influence subsequent processing. After patient identification has been considered, clinical details are critical and for virtually all serological tests, knowledge of the date of onset of illness is vital.

The decision on which tests to perform on "clinical syndrome" requests often falls to the microbiology laboratory and although this type of request comprises only a small percentage of overall specimen numbers, it may generate a significant amount of work for both laboratory and medical staff within the department. In an attempt to analyse how microbiology departments process such serological requests and to look for potential ways of improving the service, a study was undertaken in 10 district laboratories of the Oxford region. 
Table 1 Questionnaire on serological testing of infectious "clinical syndrome" requests

\begin{tabular}{|c|c|c|}
\hline Q.1 & Total number of specimens processed in microbiology annually & \\
\hline Q.2 & Total number of specimens processed in virology/serology during 2 month period of study & \\
\hline Q.3 & Total number of "clinical syndrome" requests processed during 2 month period of study & \\
\hline Q.4 & $\begin{array}{l}\text { What happens to "clinical syndrome" requests after arrival in the laboratory? } \\
\text { How are decisions made on which tests to perform? } \\
\text { a) Are there laboratory protocols for specific "clinical syndromes" described? } \\
\text { b) Are requests reviewed by MLSO staff and tests decided by them? } \\
\text { c) Are requests reviewed by medical staff and tests decided by them? } \\
\text { d) Are requests reviewed mainly by MLSO staff with review by medical staff on some } \\
\text { occasions? } \\
\text { If answer d), under what circumstances are requests reviewed by medical staff? }\end{array}$ & $\begin{array}{l}\text { YES/NO } \\
\text { YES/NO } \\
\text { YES/NO } \\
\text { YES/NO }\end{array}$ \\
\hline Q.5 & Under what circumstances are second (convalescent) serum samples requested? & \\
\hline Q.6 & When a second serum is needed, how is the request made ie by telephone or written report? & \\
\hline Q.7 & $\begin{array}{l}\text { When a second serum is requested, are further clinical details including date of onset of } \\
\text { illness } \\
\text { a) automatically asked for? } \\
\text { b) only asked for if not adequate with first request? } \\
\text { c) not asked for? }\end{array}$ & $\begin{array}{l}\text { YES/NO } \\
\text { YES/NO } \\
\text { YES/NO }\end{array}$ \\
\hline Q.8 & $\begin{array}{l}\text { When a second serum is requested, is a time interval between serum samples suggested to } \\
\text { the clinician? }\end{array}$ & YES/NO \\
\hline Q.9 & $\begin{array}{l}\text { Does the time interval advised vary for different "clinical syndromes"? } \\
\text { If yes, give details }\end{array}$ & YES/NO \\
\hline Q.10 & $\begin{array}{l}\text { If a second serum is requested but not received } \\
\text { a) what action is taken by the laboratory? } \\
\text { b) would tests be performed on the first serum sample only } \\
\text { If yes, under what circumstances? }\end{array}$ & YES/NO \\
\hline Q.11 & How long are serum samples from "clinical syndrome" requests kept? & \\
\hline Q.12 & $\begin{array}{l}\text { In "clinical syndrome" investigations, results are often obtained at varying times according to } \\
\text { batch testing, referral to other laboratories etc. Are results reported } \\
\text { a) as each individual test is completed? } \\
\text { b) as batches of tests are completed? } \\
\text { c) when all tests are completed including reference laboratory results? }\end{array}$ & $\begin{array}{l}\text { YES/NO } \\
\text { YES/NO } \\
\text { YES/NO }\end{array}$ \\
\hline Q.13 & $\begin{array}{l}\text { Are comments added to reports to help the clinician with interpretation } \\
\text { a) always? } \\
\text { b) sometimes? } \\
\text { c) never? } \\
\text { If only sometimes, under what circumstances would comments be added? }\end{array}$ & $\begin{array}{l}\text { YES/NO } \\
\text { YES/NO } \\
\text { YES/NO }\end{array}$ \\
\hline Q.14 & $\begin{array}{l}\text { The following are examples of the most common "clinical syndrome" type requests. Name } \\
\text { the tests that would be considered part of routine serological investigations for each } \\
\text { syndrome described } \\
\text { a) } 50 \text { year old male, with ? atypical pneumonia. } \\
\text { b) } 20 \text { year old female, with persistent general malaise following viral illness. } \\
\text { c) } 35 \text { year old male, with fever and cervical lymphadenopathy. } \\
\text { d) } 40 \text { year old female, with general malaise, abnormal liver function tests, ? hepatitis. } \\
\text { e) } 30 \text { year old female, with 'flu-like illness and arthralgia. } \\
\text { f) } 50 \text { year old male, with ? pericarditis. }\end{array}$ & \\
\hline
\end{tabular}

\section{Methods}

The Oxford region contains 10 microbiology departments all of which receive specimens from their local inpatients and outpatients departments and from general practitioners. One district has separate bacteriology and virology/serology departments so that for the purposes of this study, only the virology/serology section contributed. This same district acts as a referral serology unit for most of the other nine departments. One other laboratory associated with Royal Air Force services receives a significant number of serology specimens from military sources both home and abroad.

The study was conducted in two parts. Firstly, a questionnaire was distributed to each laboratory for comparison of the procedures used for processing "clinical syndrome" requests (table 1). A "clinical syndrome" request was defined as a request for serological investigations on a patient whose details only give a general description of a suspected underlying infectious illness. The illness could be acute and specific such as atypical pneumonia, or chronic with only vague signs and symptoms described-for example, general malaise following influenza-like illness.

The second part of the study consisted of a prospective collection of data on "clinical syndrome" requests received by the 10 departments over the two month period, June/July 1993. A table was designed and distributed to all laboratories for data collection. Each laboratory was asked to record the following information:

1 Does the request form contain adequate patient details by giving the full name, age and sex?

2 State the clinical details and/or suspected diagnosis given by the clinician.

3 Does the request give enough clinical information to allow an immediate decision on appropriate tests to be performed?

4 Is the date of onset of illness given?

5 Has the clinician requested specific tests he/she wishes the laboratory to perform?

6 Has the clinician left the decision to the laboratory by requesting "viral titres" or equivalent?

7 Do the laboratory staff (either technical or medical) consider it necessary to directly contact the requesting clinician to gain more details about the case?

8 Is a second (convalescent) serum considered necessary?

9 Has a second specimen been received and if so the date taken?

10 Is further clinical information given with the second serum?

11 How many tests are performed at the primary laboratory?

12 How many tests are performed at reference laboratories?

13 Record the time interval between arrival of the first request and the report of the final 


\begin{tabular}{|c|c|c|c|c|c|c|c|c|c|c|}
\hline & \multicolumn{10}{|c|}{ Laboratory } \\
\hline & 1 & 2 & 3 & 4 & 5 & 6 & 7 & 8 & 9 & 10 \\
\hline $\begin{array}{l}\text { Total number of specimens processed in microbiology dept. } \\
\text { annually }\end{array}$ & $-t$ & 113000 & 158000 & 131000 & 165000 & 37000 & 92000 & 24000 & 110000 & 116000 \\
\hline $\begin{array}{l}\text { Total number of specimens processed in virology/serology } \\
\text { section of dept. annually* }\end{array}$ & 50000 & 17000 & 31000 & 18500 & 11100 & 5000 & 22800 & 8200 & 22000 & 18000 \\
\hline Total number of "clinical syndrome" requests annually* & 2900 & 1300 & 4000 & 1600 & 1300 & 400 & 800 & 1300 & 1100 & 1700 \\
\hline$\%$ "Clinical syndrome" requests of virology/serology total & 6 & 8 & 13 & 9 & 12 & 8 & 4 & 16 & 5 & 9 \\
\hline$\%$ "Clinical syndrome" requests of microbiology total & $-\dagger$ & 1 & $2 \cdot 5$ & 1 & 1 & 1 & 1 & 5 & 1 & $1 \cdot 5$ \\
\hline
\end{tabular}

* Total numbers extrapolated from figures collected over the two month study period.

† Laboratory 1 has separate bacteriology department not involved in this study.

results (including those from reference laboratories) sent to the clinician.

14 With the investigations performed, has a significant positive result been found?

A list of specimens and requests commonly received by virology/serology laboratories, but to be excluded from the study, was also distributed. This comprised the following: all swabs/aspirates for viral culture/antigen testing; other miscellaneous material (for example, cerebrospinal fluid, faeces) sent for viral culture/ antigen testing; all antenatal serology; all hepatitis $B$ vaccination associated serology; all hepatitis $B$ antigen screening - for example, predialysis, preoperation; all specific HIV and syphilis serology requests originating from Genito-urinary clinics, insurance requirements, etc.; all "immunological" type requests-for example, complement levels, C-reactive protein; and all chlamydial culture/antigen tests.

All data was returned to the author one month after the period of study to allow for the arrival of convalescent serum samples from requests received in July.

\section{Results}

The results from the questionnaire arm of the study were as follows:

Questions 1-3-“Clinical syndrome" requests comprise $8-10 \%$ of virology/serology specimens annually and $1-2 \%$ of total $\mathrm{mi}-$ crobiology samples across the Oxford region (table 2). Laboratory 8 had a higher percentage of "clinical syndrome" specimens because of requests originating from military sources.

Question 4-Six departments use protocols to guide MLSO staff on which tests to perform. One laboratory uses MLSO review of each individual request with medical referral if necessary, whilst in three laboratories review of requests is carried out solely by medical staff. Reasons given for medical review in the protocol directed units include inadequate information not conforming to a protocol, no date of onset given, or request considered to be of specific medical interest.

Question 5-Second or convalescent serum samples are requested according to (1) the date of onset given, (2) the type of illness or clinical details described, (3) the type of test available-for example, paired serum samples would always be required if complement fixation tests (CFTs) were the method of test, (4) the protocol directive.
Question 6-Five departments only send a written (computer) report asking for a second serum sample, whilst the other $50 \%$ also telephone the clinician directly depending on the case.

Question 7-Only two laboratories automatically ask for further clinical details to accompany a second serum whilst three others request them if inadequate details were supplied with the first sample. Five laboratories make no mention of the importance of further information such as the date of onset of illness.

Questions 8 and 9-All 10 departments suggest time intervals between serum samples. However, three give no variation in time interval for different "clinical syndromes", four units vary their advice for some suspected infections such as Borrelia or Legionella, whilst three laboratories state a time interval according to the individual case. Around 10 days is the most common time gap suggested.

Question 10-If a second serum fails to arrive, six laboratories take no further action whereas four units send a report after three to four weeks reminding the clinician that a second sample is still awaited. Only two departments would not perform any serology on an acute serum sample alone. Seven units would carry out tests if the clinical details suggested an infection for which a single titre could still be diagnostic. This would particularly depend on the date of onset, if known, and the type of test. One laboratory tests all serum samples even if convalescent specimens fail to appear.

Question 11-Serum samples are stored for widely varying periods of time. One laboratory only keeps aliquots for one month, four laboratories store for up to four months, three units keep serum samples for 12 months, and two departments manage to store for several years.

Question 12-There are significant differences in result reporting. One laboratory waits for all tests to be completed before sending a report whilst three departments release test results as they are individually completed. Six units send reports as batches of tests are finished.

Question 13-Three departments always add interpretative comments to reports whilst the other seven units add comments in specific cases only. Examples quoted where comments may be added include all CFT results, single serum results, when reporting IgM and IgG levels, or "if requester is unlikely to understand the result". 
Table 3 Examples of "clinical syndromes" and range of infections tested by 10 laboratories (Q.14 in questionnaire). Figures in parentheses represent number of laboratories performing tests

\begin{tabular}{|c|c|c|}
\hline (a) & 50 year old man, ? atypical pneumonia & $\begin{array}{l}\text { Mycoplasma (10), Legionella (10), Q fever (10), Chlamydia (9), Influenzae } \\
\text { A+B (9), Adenovirus ( } 7) \text {, Respiratory syncytial virus (5), Cytomegalovirus } \\
\text { (2), Enterovirus (1) }\end{array}$ \\
\hline (b) & $\begin{array}{l}20 \text { year old woman, persistent malaise } \\
\text { following viral illness }\end{array}$ & $\begin{array}{l}\text { Epstein-Barr virus (8), Cytomegalovirus (6), Toxoplasma (6), Enterovirus (6), } \\
\text { Mycoplasma (4), Influenzae A+B (4), Adenovirus (3), Chlamydia (2), } \\
\text { Q fever (2), Respiratory syncytial virus (1), Mumps (1), None (1) }\end{array}$ \\
\hline (c) & $\begin{array}{l}35 \text { year old man, fever and cervical } \\
\text { lymphadenopathy }\end{array}$ & $\begin{array}{l}\text { Epstein-Barr virus (10), Toxoplasma (10), Cytomegalovirus (8), Anti- } \\
\text { streptolysin O titre (2), Mumps (2), Mycoplasma (1), Chlamydia (1), } \\
\text { Influenzae A + B (1), Adenovirus (1), Enterovirus (1), Rubella (1), Herpes } \\
\text { simplex virus (1), HIV (1), Respiratory syncytial virus (1) }\end{array}$ \\
\hline (d) & $\begin{array}{l}40 \text { year old woman, general malaise, } \\
\text { abnormal liver function tests, ? hepatitis }\end{array}$ & $\begin{array}{l}\text { Hepatitis B virus (10), Hepatitis A virus (10), Cytomegalovirus (8), } \\
\text { Epstein-Barr virus ( } 7 \text {, Hepatitis C virus (2), Leptospira (2), Toxoplasma (1), } \\
\text { Mycoplasma (1), Legionella (1), Q fever (1) }\end{array}$ \\
\hline (e) & $\begin{array}{l}30 \text { year old woman, 'flu-like illness and } \\
\text { arthralgia }\end{array}$ & $\begin{array}{l}\text { Rubella (10), Parvovirus (9), Mycoplasma (8), Influenzae A+B (7), } \\
\text { Chlamydia (5), Adenovirus (4), Enterovirus (4), Hepatitis B virus (4), } \\
\text { Q fever (4), Epstein-Barr virus (3), Anti-streptolysin O titre (3), Borrelia (3), } \\
\text { Mumps (2), Respiratory syncytial virus (2), Yersinia (2), Legionella (1), } \\
\text { Toxoplasma (1), Syphilis (1), Cytomegalovirus (1) }\end{array}$ \\
\hline (f) & 50 year old man, ? pericarditis & $\begin{array}{l}\text { Enterovirus (10), Mycoplasma (7), Influenzae A+B ( } 7), Q \text { fever (7), } \\
\text { Chlamydia (7), Adenovirus (5), Epstein-Barr virus (2), Cytomegalovirus (2), } \\
\text { Legionella (1), Mumps (1), Anti-streptolysin O titre (1), Respiratory syncytial } \\
\text { virus (1) }\end{array}$ \\
\hline
\end{tabular}

Question 14-See table 3. In example (a) there is a broad agreement over the range of tests considered appropriate. Example (b) provides a wider spectrum of investigations but one laboratory argues that there are no appropriate tests for this kind of clinical picture. General consensus is reached for example (c) with the same three tests performed by eight laboratories. In example (d) investigations for acute hepatitis A or B are unanimous, but some other potential pathogens are sought if tests for hepatitis A and B prove negative. The widest range of responses is given to example (e) with 19 different infections investigated. The only pathogen appearing on all laboratory lists is rubella. With example (f), the same five potential pathogens are investigated by seven departments.

A summary of the prospective data collected by the 10 departments for the second part of the study is given in table 4 . One laboratory was unable to provide the majority of data requested because of staffing difficulties during the study period.
Most laboratories received requests with adequate patient details in over $90 \%$ of cases but in two units, up to $15 \%$ of forms lacked full patient information. There was a wider variation in the assessment of whether requests provided adequate clinical details (range 60 $96 \%$ ). Three units with a lower percentage of adequate clinical information were also not using protocols. Only three laboratories received dates of onset of illness on more than $40 \%$ of requests. Each department was asked to provide a copy of the serology form used by their clinicians and in three laboratories with poor date of onset information, the card lacked a specific request box for this data. By contrast, the three laboratories with a response of over $40 \%$ specifically ask for a date of onset on their serology forms.

Across the region, clinicians demanded specific tests in approximately $50 \%$ of "clinical syndrome" cases. A general request for "viral titres" or some similar description was given on $50 \%$ of forms. Departments varied widely in their use of direct clinician contact. Half of

Table 4 Summarised data of "clinical syndrome" requests received from 10 departments over the two month period

\begin{tabular}{|c|c|c|c|c|c|c|c|c|c|c|c|}
\hline & & \multicolumn{10}{|c|}{ Laboratory } \\
\hline & & 1 & 2 & 3 & 4 & 5 & 6 & 7 & 8 & 9 & 10 \\
\hline 1 & $\begin{array}{l}\text { \% Requests giving adequate patient } \\
\text { details }\end{array}$ & 90 & 92 & 92 & 85 & 94 & 87 & 100 & 99 & 89 & 94 \\
\hline 2 & $\begin{array}{l}\% \text { Requests giving adequate clinical } \\
\text { details to decide on which tests }\end{array}$ & 86 & 80 & 95 & 88 & NA & 60 & 66 & 96 & 67 & 81 \\
\hline 3 & $\begin{array}{l}\% \text { Requests giving date of onset of } \\
\text { illness }\end{array}$ & 43 & 46 & 30 & 28 & NA & 30 & 29 & 11 & 44 & 20 \\
\hline $\begin{array}{l}4 \\
5\end{array}$ & $\begin{array}{l}\% \text { Requests asking for specific tests } \\
\% \text { Requests asking for "viral titres" or } \\
\text { equivalent }\end{array}$ & $\begin{array}{l}55 \\
55\end{array}$ & $\begin{array}{l}52 \\
49\end{array}$ & $\begin{array}{l}45 \\
55\end{array}$ & $\begin{array}{l}65 \\
42\end{array}$ & $\begin{array}{l}74 \\
30\end{array}$ & $\begin{array}{l}45 \\
69\end{array}$ & $\begin{array}{l}60 \\
44\end{array}$ & $\begin{array}{l}35 \\
71\end{array}$ & $\begin{array}{l}24 \\
81\end{array}$ & $\begin{array}{l}72 \\
31\end{array}$ \\
\hline 6 & $\begin{array}{l}\% \text { Requests needing direct clinician } \\
\text { contact }\end{array}$ & 2 & 14 & 1 & 13 & NA & 4 & 29 & 1 & 51 & 2 \\
\hline $\begin{array}{l}7 \\
8 \\
0\end{array}$ & $\%$ Requests needing second serum & NA & $\begin{array}{l}59 \\
53 \\
25\end{array}$ & $\begin{array}{l}15 \\
35\end{array}$ & $\begin{array}{l}41 \\
20\end{array}$ & NA & 22 & $\begin{array}{l}63 \\
29\end{array}$ & $\begin{array}{l}33 \\
39\end{array}$ & $\begin{array}{l}79 \\
44\end{array}$ & $\begin{array}{l}37 \\
29 \\
10\end{array}$ \\
\hline 9 & $\begin{array}{l}\text { \% Second samples giving further } \\
\text { clinical details }\end{array}$ & NA & 35 & 0 & 29 & NA & 20 & 17 & 4 & 30 & 19 \\
\hline 10 & $\begin{array}{l}\% \text { Tests performed at primary } \\
\text { laboratory }\end{array}$ & 95 & 48 & 85 & 47 & NA & 3 & 46 & 97 & 50 & 49 \\
\hline 11 & $\begin{array}{l}\% \text { Tests performed at reference } \\
\text { laboratory(s) }\end{array}$ & 5 & 52 & 15 & 53 & NA & 97 & 54 & 3 & 50 & 51 \\
\hline 12 & $\begin{array}{l}\text { Average time (days) between first } \\
\text { serum and final report: } \\
\text { (a) if tests performed at primary } \\
\text { laboratory only; }\end{array}$ & 8 & 7 & 8 & 5 & NA & 8 & 6 & 7 & NA & 4 \\
\hline & $\begin{array}{l}\text { (b) if tests also performed at } \\
\text { reference laboratory(s) }\end{array}$ & NA & 22 & 21 & 21 & NA & 15 & 19 & 19 & 21 & 19 \\
\hline 13 & $\begin{array}{l}\% \text { Requests producing a significant } \\
\text { positive result }\end{array}$ & 7 & 19 & 14 & 8 & 8 & 7 & 18 & 17 & 10 & 10 \\
\hline
\end{tabular}

NA $=$ data not available. 
the laboratories rarely contacted a clinician ( $<5 \%$ of requests) whereas in two units, doctors were consulted regarding approximately $30 \%$ and $50 \%$ of specimens. Investigations requiring second serum samples varied from 15 to $79 \%$ (average $42 \%$ ) but when a convalescent sample had been asked for, only one laboratory obtained a $50 \%$ response (average $35 \%$ ). There was also a failure to obtain further clinical details with the second serum sample in 65$100 \%$ of cases. Laboratories 1 and 3 perform most serological investigations in-house as they are also Public Health Laboratories. Laboratory 6 is a small unit sending nearly all serology to laboratory 1 . Laboratory 8 , although small, is a more self-sufficient unit as it handles military source specimens. The other six departments are similar in terms of representing large district laboratories which require the help of secondary reference units for some serological tests. The ratio of tests performed within the primary laboratory and those sent to reference laboratories was remarkably consistent at a ratio of $1: 1$ across these six districts.

From the data collected by most units, it was possible to calculate the average time taken to complete investigations on a "clinical syndrome" request for both in-house and reference serology. An average of 6.5 days was taken to complete in-house investigations whilst work requiring reference testing took an average of $20 \cdot 2$ days. The number of "clinical syndrome" requests producing a significant positive result varied across the region with some laboratories achieving over double the rate of others (average 12\%).

\section{Discussion}

Over recent years there have been several studies of the use of hospital clinical laboratories ${ }^{45}$ and in particular the appropriateness of tests carried out and the efficiency of resources available. Serology is not a discipline that has received much attention but most clinical microbiologists throughout the United Kingdom will be only too aware of the intrinsic problems that their serological workload presents. The most difficult aspect is the processing of requests from patients with "clinical syndromes" suggestive of possible infectious disease.

Clinicians vary greatly in their test ordering behaviour. One publication listed 32 different reasons for ordering a test including "frustration at nothing else to do". When clinicians face patients complaining of vague symptoms such as general malaise or myalgia/arthralgia, there is an almost automatic tendency for a serum sample to be taken for "viral titres". This study is the first to attempt to show how clinical laboratories in one region manage such requests.

As expected, "clinical syndrome" requests contributed a fraction to the total of microbiology specimens and even within the serology section itself, these samples formed a small minority of overall numbers. For "clinical syndrome" requests basic patient details may influence which tests are performed. A return from two laboratories of less than $90 \%$ adequately completed patient details was unsatisfactory. The use of laboratory protocols for serology tests has advantages and disadvantages. Their application can lessen the need for more detailed clinical information and can improve the efficiency of the laboratory but they may encourage increased unnecessary testing because they are by definition designed for an average patient. ${ }^{7}$ Protocols or guidelines are more likely to succeed if they are agreed jointly by laboratory staff and clinicians, with regular review, but achieving consensus on the criteria for whether a test is appropriate for a particular clinical setting is problematic. Progress, however, can be achieved and in the author's own district, following discussions with relevant clinical colleagues, laboratory guidelines have been drawn up for the most appropriate tests to be performed on patients with a history of influenza-like illness followed by arthralgia, one of the most common "clinical syndrome" type requests. Clinician education in the use of the laboratory, in the form of lectures, seminars or guidelines, has been proposed as the most promising long term approach to influencing test ordering behaviour. ${ }^{8}$ Many clinicians are unaware of how best to investigate, which tests to order and how much clinical information to give the laboratory especially on "clinical syndrome" type patients. The finding that $50 \%$ of forms asked for "viral titres" demonstrates clinicians' ignorance and highlights the responsibility given to laboratories as the clinician has, in effect, passed over decision making on appropriate investigations to the laboratory.

In this study two units declared that serological testing would not be performed solely on acute serum samples; such a policy must undoubtedly result in missed diagnoses. In another department, investigations are carried out on every sample which must lead to a number of inappropriate tests with the added concern that single titre results could mislead the clinician. A review of both these extremes of practice was advised in the departments concerned. Storage space is the obvious limiting factor for determining how long laboratories are able to keep serum samples. However, the occasional need to re-examine serum samples is so important that all laboratories should be encouraged to store serum samples for a minimum of six months and preferably one year. The percentage of requests quoting a date of onset of illness was disappointingly low in this study. Knowledge of the date of onset of a suspected infectious illness is often critical not only for making decisions on which tests to perform but also on the interpretation of subsequent results. A simple amendment to the request form, specifically asking for a date of onset should improve this response.

Acute serum samples from some "clinical syndrome" type patients will inevitably become redundant as subsequent clinical events or other investigations reveal a diagnosis, but testing of paired serum samples in parallel is almost obligatory for the diagnosis of some infections. 
In this study $50 \%$ of laboratories took no action if second serum samples failed to arrive. This indoubtedly contributed to the poor response seen to second serum sample requests (average $35 \%$ ). Additional clinical details rarely accompanied the second serum sample but only half of the laboratories specifically asked clinicians for further information. As a consequence, departments were urged to review their procedures both in the way they request second serum samples and the action taken when convalescent samples fail to arrive. A second serum sample response rate of $50 \%$, achieved by one unit, should be an attainable goal, and the development of computer systems for requesting, processing and reporting tests ${ }^{9}$ should improve this response further in the future. Most serological investigations are performed in batches and testing within the primary unit will depend on individual laboratory working practices. Results from this study show that an average turnround time of under seven days is possible. When serum samples are despatched to reference laboratories, the turnround time is significantly extended. In this survey three units achieved an average time of 19 days for dispatched samples whilst four other departments took 21 to 22 days. The latter group were encouraged to review their dispatch procedures as a potential improvement of two to three days seemed achievable.

The majority of "clinical syndrome" requests will not detect any significant abnormality but it is not known whether an average positive result rate of $12 \%$ is acceptable as similar analyses on serological testing have not been published. The finding that some units obtained positive result rates two to three times greater than others may, in part, be because of different subjective interpretations of serological results. For example, different laboratories may have interpreted a significant positive result as (1) any positive titre to any antigen, (2) a single titre above "normal", or (3) a rising titre to an organism likely to have caused the illness specified. The wide variation in positive result rates also suggests that improvements in the range and performance of relevant tests and the ability to gather more precise information from clinicians together with more con- valescent specimens are all areas of the serology service which need review.

In biochemistry departments in particular, it has been shown that laboratories respond differently to the same clinical request. ${ }^{10}$ The production of prompt reliable laboratory results will contribute little to patient outcome if the tests performed are clinically inappropriate or redundant and the efficient use of pathology resources is diminished. This study is the first to analyse the processing of serology specimens in an area of particular difficulty for clinical microbiologists and their departments. Use of the serology service, as applied to "clinical syndrome" type problems, has been described within 10 departments in the Oxford region and practices in need of review and improvement have been highlighted. This study is likely to be representative of many serology departments across the country and it is hoped that the findings may stimulate other laboratories to analyse the procedures and outcomes for similar areas of their work.

Thanks are due to all medical and laboratory staff within the microbiology departments of the following hospitals: Horton General Hospital, Banbury; RAF Halton Hospital, Aylesbury, Kettering and District General Hospital, Kettering; Milton Keynes Hospital, Milton Keynes; Northampton General HosReynes Hospital, Milton Keynes; Northampton General Hospital, Northampton; John Radcliffe Hospital, Oxford; Royal Stoke Mandeville Hospital, Aylesbury; Wycombe General Hospital, High Wycombe.

1 Department of Health. The Pathology Services. A Management Review. The Audit Commission for local authorities in The National Health Service of England and thorities in The National Health

2 Bareford D, Hayling A. Inappropriate use of laboratory services: long term combined approach to modify request services: long term combined app

3 Wong ET, Saxena S. Medical appropriateness of laboratory tests. Am f Clin Pathol 1992;97:748-50.

4 Young DW. Improving laboratory usage: a review. Postgrad Med f 1988;64:283-9.

5 Peters $M$, Broughton PM, Nightingale PG. Use of information technology for auditing effective use of laboratory services. F Clin Pathol 1991;44:539-42.

6 Lundberg GD. Using the clinical laboratory in medical decision-making. Chicago: American Society of Clinical Pathologists Press, 1983:viii-ix.

7 Fraser CG, Woodford FP. Strategies to modify the test requesting patterns of clinicians. Ann Clin Biochem 1987; requesting

8 Marton KI, Tul V, Sox HC. Modifying test-ordering behaviour in the outpatient medical clinic. A controlled trial of two educational interventions. Arch Intern Med 1985, 145:816-21.

9 Winkel P. Automated decision making in relation to laboratory test requests. Scand $\mathcal{F}$ Clin Lab Invest Suppl 1990;202 120-2.

10 Broughton PM, Worthington DJ. Laboratories respond differently to the same clinical request. Ann Clin Biochem 1989;26:119-21. 